\title{
Detrital zircon and apatite fission track data in the Liaoxi basins: Implication to Meso-Cenozoic thermo-tectonic evolution of the northern margin of the North China Craton
}

\author{
Yi Yan ${ }^{1, *}$, Xiaoqiong Hu${ }^{1},{\text { Ge } \text { Lin }^{1} \text {, Weiliang Liu }}^{1}$ and Zhenguiang Song ${ }^{2}$ \\ ${ }^{1}$ Key Laboratory of Marginal Sea Geology, Guangzhou Institute of Geochemistry, \\ Chinese Academy of Sciences, Wushan, Guangzhou, 510 640, P. R. China. \\ ${ }^{2}$ Tou Tay Oilfield Development Company Limited DaQing, Heilongjiang, 151 300, P. R. China. \\ *e-mail: yanyi@gig.ac.cn
}

\begin{abstract}
Detrital zircon and apatite fission track (ZFT and AFT) data of the sandstones collected from the Liaoxi basins served as a significant probe to study the Meso-Cenozoic thermo-tectonic reactivation events in the northern margin of the North China Craton. All sandstones show wide ZFT and AFT age spectrum and most of ZFT and AFT ages are younger than depositional age of respective host rocks, which suggest widespread track resetting of the host rocks in the Liaoxi basins after deposition. This hot geothermal status in the Liaoxi basins deduced from ZFT and AFT data is temporal consistent with the lithospheric evolution of the North China Craton, which implies that the lithosphere under the northern margin of the North China Craton underwent similar thermo-tectonic destruction process as the intracratonic Bohai Sea. The young ZFT peak age, which ranges from $\sim 50 \mathrm{Ma}$ to $20 \mathrm{Ma}$, to some extend, provides a temporal constraint on the time that lithosphere significantly thinned and following reverse of the Liaoxi basins and uplift of the eastern part of the Yan-Liao Orogenic Belt. Exhumation of 1.5-2 km can be estimated in the eastern part of the Yan-Liao Orogenic Belt since $\sim 30 \mathrm{Ma}$ to $10 \mathrm{Ma}$.
\end{abstract}

\section{Introduction}

Re-activation of the North China Craton during Mesozoic time is one of the most important tectonic events in East Asia (Griffin et al 1998; Menzies and Xu 1998; Fan et al 2000; Zheng et al 2001; Gao et al 2004; Menzies et al 2007; Zhang et al 2007). Occurrence of Ordovician diamondiferous kimberlites in the North China Craton provides evidence for the existence of $>150 \mathrm{~km}$ thick cratonic lithosphere in Early Paleozoic time (Griffin et al 1998; Menzies and Xu 1998; Zheng et al 2001; Gao et al 2002; Santosh 2010; Santosh et al 2010), while mantle xenolith from the Cenozoic basalts describes a thinner and hotter lithosphere at Recent times (Menzies and Xu 1998; Fan et al 2000; Zheng et al 2001; Wu et al 2003; Gao et al 2004). Presence of such a thin lithosphere $(70-80 \mathrm{~km})$ and high heat flow $\left(50-105 \mathrm{~mW} / \mathrm{m}^{2}\right)$ is consistent with geophysical observations (Chen et al 1991, 2008, 2009; Zhang 1998; Tian et al 2009; $\mathrm{Xu}$ and Zhao 2009; Chen 2010).

The Liaoxi basins lie in the northern margin of the North China Craton, which developed during Jurassic-Cretaceous time accompanied by intensive magmatism and tectonic re-activation. Although the thermo-tectonic destruction of the lithospheric keel beneath the North China Craton was recognized decades ago (Griffin et al 1998; Menzies and $\mathrm{Xu}$ 1998), whether the northern

Keywords. Lithosphere thinning; zircon fission track (ZFT); apatite fission track (AFT); Liaoxi basins; North China Craton (NCC). 
margin of the North China Craton experienced the similar mechanisms or not still remain unclear (Chen 1998; Davis et al 2001; Zhang et al 2003; Gao et al 2004). As a part of the Yan-Liao Orogenic Belt, several extensional and contractional events occurred in the Liaoxi area during Meso-Cenozoic (Davis et al 1990, 1998, 2001) and the Yan-Liao Orogenic Belt experienced inhomogeneous uplift in the Cenozoic ( $\mathrm{Wu}$ et al 2000). What is the uplift sequence of the eastern part of the Yan-Liao Orogenic Belt are not well estimated.

Kilometer-scale sedimentary rocks were deposited in the Liaoxi basins during MesoCenozoic, which can serve as a significant probe to reveal the Meso-Cenozoic thermo-tectonic reactivation events in the northern margin of the North China Craton (figure 1a). In this paper, detrital zircon and apatite fission track (AFT and ZFT) ages of the sedimentary rocks from the Liaoxi basins are presented. The purposes of this study are:

- to study the geothermal status of the basins to understand lithosphere evolution;

- to document the exhumation process of the Liaoxi area to understand how much rocks eroded in the eastern part of the Yan-Liao Orogenic Belt.

\section{Regional geology}

The North China Craton is surrounded by the Paleozoic to Triassic Qinling-Dabie-Sulu Orogenic Belt in the south ( $\mathrm{Li}$ et al 1993; Meng and Zhang 2000; Wu et al 2007; Hou et al 2010) and Central Asian Orogenic Belt in the north (figure 1a; Davis et al 2001; Xiao et al 2003, 2009, 2010). The North China Craton is traditionally be considered as a collage of two discrete crustal blocks namely, the eastern block and the western block with the intervening Central Orogenic Belt, also known as the Trans-North China Orogen, which is believed to represent a collision zone resulting from the amalgamation of the eastern and western blocks (e.g., Zhao et al 2002, 2005, 2008, 2009, 2010; Trap et al 2009; Santosh 2010; Santosh et al 2010). As one of the largest and oldest cratons in East Asia, the regional metamorphic basement of the North China Craton is composed of Archean crystalline rocks with oldest rock up to $3.8 \mathrm{Ga}$ (Liu et al 1992). Early Proterozoic neritic sediments (ca. 1850-1800 Ma) are widespread, but of variable total thickness $(0 \mathrm{~m}$ to $>10 \mathrm{~km})$ and the Later Proterozoic (Sinian), ca. 800-615 Ma, are missing. Paleozoic strata on the craton are represented by:

- Cambrian-Middle Ordovician deposits dominated by neritic carbonates;
- The Upper Carboniferous-Lower Permian alternating marine and terrestrial sequences, characterized by carbonates and coal-bearing clastic rocks, respectively;

- Upper Permian-Triassic terrestrial sandstones and conglomerates (Bureau of Geology and Mineral Resources of Liaoning Province 1989).

By the end of the Middle Triassic, the southdirected compression led to the deformation of preMesozoic strata and the formation of a series of east-northeast-trending fold and fault belts, as well as some small-volume intracontinental basins (Davis et al 1990, 1998, 2001; Yan et al 2002). From the early Jurassic to early Cretaceous, the Yan-Liao fold and thrust belt was characterized by the intense magmatism and deformation (including multiple phases of folding and contractional, extensional, and strike-slip faulting) as a consequence of the Yanshanian event (Bureau of Geology and Mineral Resources of Liaoning Province 1989; Davis et al 1990, 1998, 2001; Ren et al 2002; Yan et al 2002; Zhang et al 2005). A serial of intracontinental basins, such as the Beipiao Basin, Jinyang Basin and Yixian Basin were developed and kilometer-scale Jurassic-Cretaceous terrestrial volcanic and clastic sediments were deposited in these basins (Bureau of Geology and Mineral Resources of Liaoning Province 1989; Yan et al 2002; Zhang et al 2005) (figure 2). Coal-bearing clastics and continental volcano-sedimentary units overlaid either Archean basement or the younger Paleozoic rocks unconformity. The late Triassic volcanic activity has been identified, but is geographically restricted. Throughout the Jurassic, mafic to intermediate volcanism is widespread in the basin and the total thickness of Jurassic rocks is about $4000 \mathrm{~m}$, including the lower Jurassic (Xinglonggou and Beipiao formations), middle Jurassic (Haifanggou and Lanqi formations) and upper Jurassic (Tuchengzi formation), mainly deposited in the Jinyang and Beipiao basins (Bureau of Geology and Mineral Resources of Liaoning Province 1989; Yan et al 2002; Zhang et al 2005). The regional volcanism reached its maximum intensity in the early Cretaceous, and the lower Cretaceous (Yixian, Jiufuotang and Fuxin formations) consists of volcanic rocks and alternating fluvial-lacustrine coal-bearing sediments including coal, conglomerate, sandstone, tuff and other volcaniclastic rocks, mainly deposited in the Yixian Basin (Bureau of Geology and Mineral Resources of Liaoning Province 1989; Yan et al 2002). Since the end of early Cretaceous, the basins were reversed and uplifted (Bureau of Geology and Mineral Resources of Liaoning Province 1989; Yan et al 2002; Meng 2003; Zhang et al 2005). 


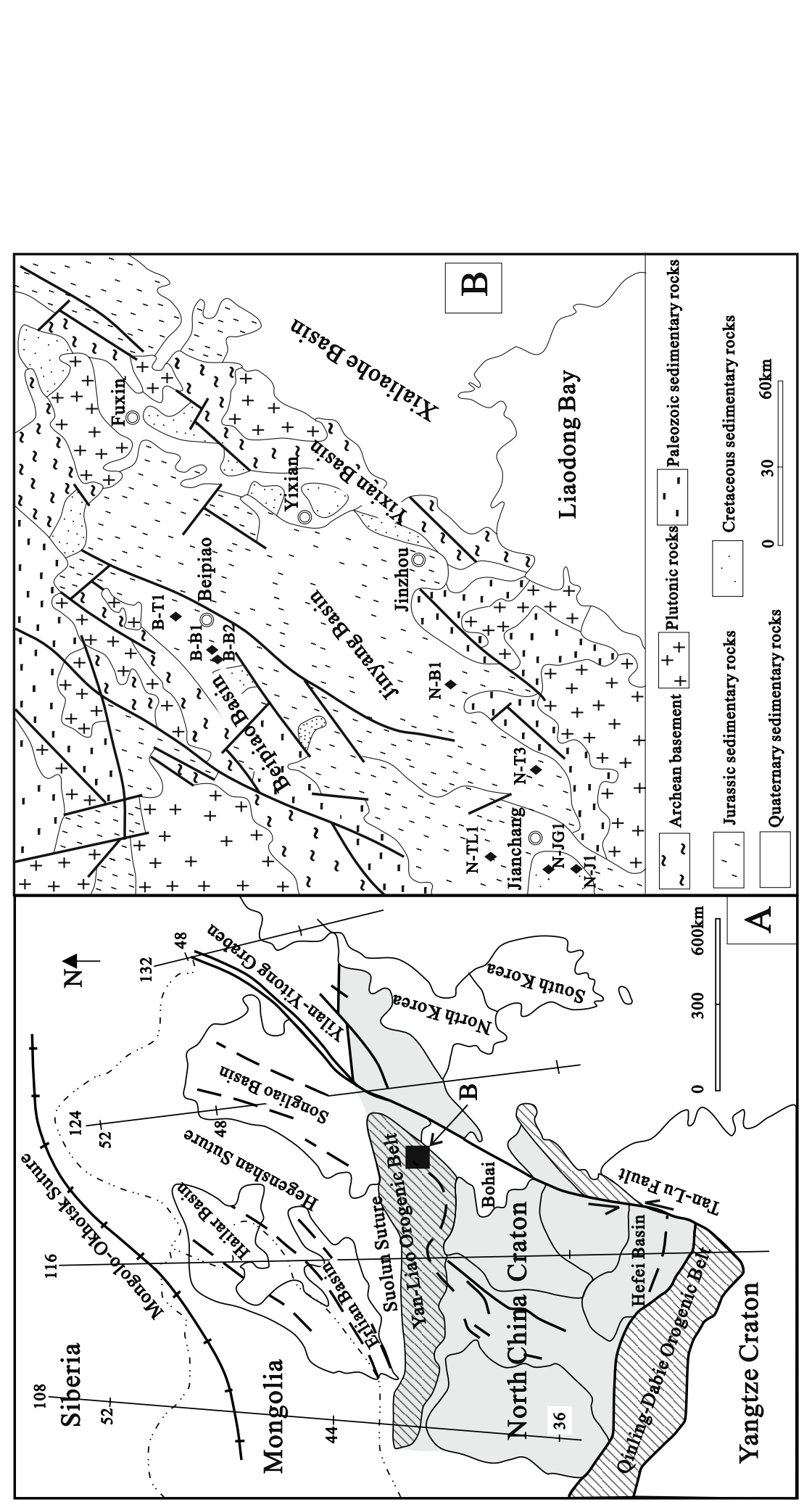




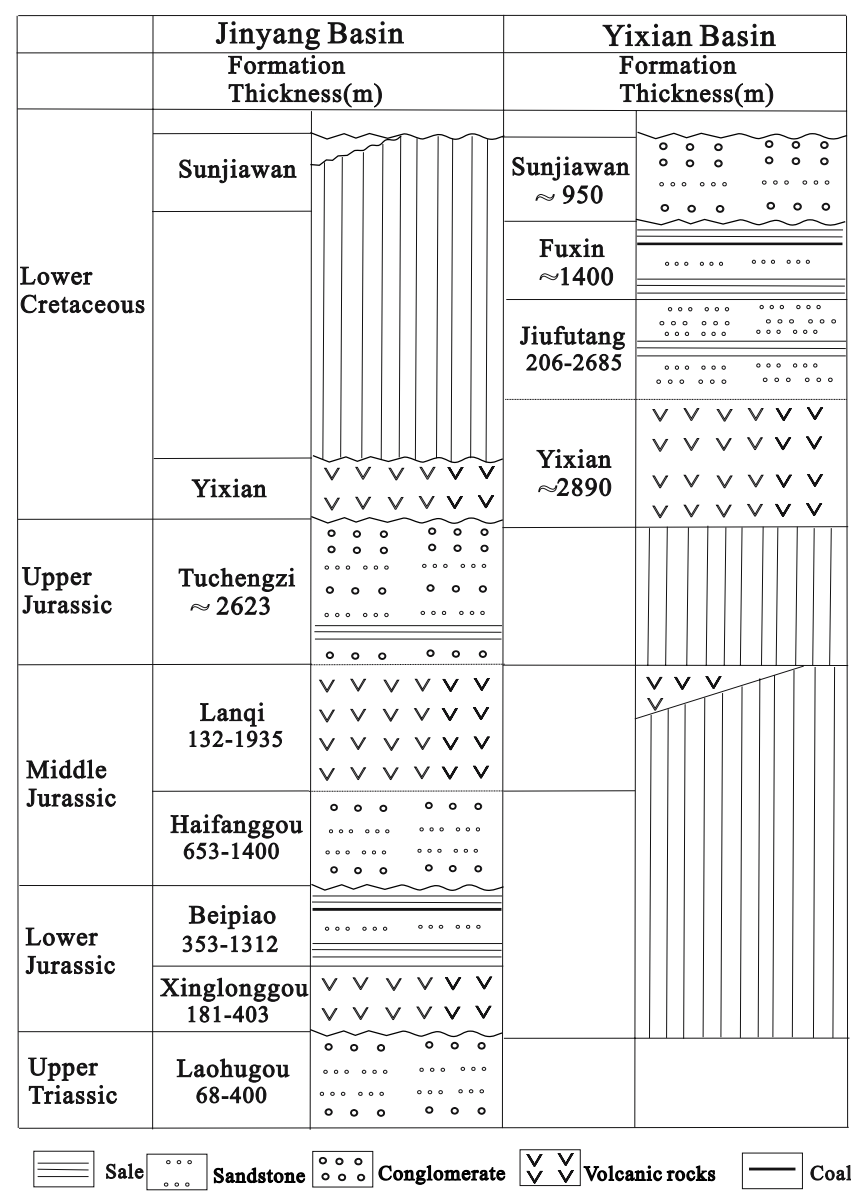

Figure 2. General stratigraphy of the Mesozoic formations in the Liaoxi area.

\section{Analysis and results}

Sandstone samples were collected from JurassicCretaceous formations in the Liaoxi basins (figure 1b). Zircon and apatite grains were extracted from rock samples using conventional magnetic and heavy liquid separation techniques. AFT and ZFT ages were performed at Fission Track Laboratory of Changsha Institute of Geotectonics, Chinese Academy of Sciences and Fission Track Laboratory of Institute of Geology, Chinese Earthquake Administration, respectively. Glass slides with apatites mounted in epoxy resin were etched using $1 \% \mathrm{HNO}_{3}$ at $20^{\circ} \mathrm{C}$ for $3 \mathrm{~min}$ and Teflon grain mounts of zircon were etched using a binary eutectic of potassium hydroxide and sodium hydroxide at $225^{\circ} \mathrm{C}$. Etched grain mounts were packed with mica external detectors and irradiated with UB2 $\left(11.2 \times 10^{-6}\right)$ and SRM612 dosimeters, respectively. Following irradiation the external detectors were etched using $40 \% \mathrm{HF}$ at $25^{\circ} \mathrm{C}$ for $20 \mathrm{~min}$. Sample ages were determined using the zeta calibration method and IUGS recommended age standards (Hurford 1990). Data are reported in table 1. Most samples yield high age dispersion $\left(P\left(\chi^{2}\right)<5 \%\right)$. ZFT central ages range from $59.2 \pm 7.8 \mathrm{Ma}$ to $124.4 \pm 17.2 \mathrm{Ma}$ and AFT central ages range from $32.9 \pm 10.9 \mathrm{Ma}$ to $109.9 \pm 15.4 \mathrm{Ma}$. Confined track lengths are relatively short between 9.68 and $11.24 \mu \mathrm{m}$ (table 1).

\section{Interpretation}

Compared with the depositional age of the respective host rocks (the deposition ages of the Laohugou, Beipiao, Tuchengzi and Yixian formations span in a range of ca. 230-190 Ma, 190-175 Ma, 160-135 Ma and 135-120 Ma, respectively) (Bureau of Geology and Mineral Resources of Liaoning Province 1989; Yan et al 2002; Zhang et al 2005), it is clear that most of the ZFT ages from each sample is significantly younger than respective stratigraphic ages (figure 3 ). It can be deduced that the samples in the Liaoxi basins were reset widespread after deposition, which is supported by apatite fission track data. Except few grains, most of AFT ages are also younger than respective stratigraphic age (figure 3 ).

High age dispersion of all the samples indicates their discordant fission-track grain age (FTGA) distributions. A common problem in FT dating is the interpretation of discordant fission-track grain age (FTGA) distributions. Mixed distributions are expected for samples that have 'detrital' FT ages, such as sandstone with unreset zircon FT ages. In this case, the grain ages preserve information about the cooling history of the source region from which the zircons were eroded, assuming that the sandstone has remained cool enough after deposition to preserve the FT ages. Reset FT samples are also commonly discordant. In some cases, the discordance is taken as an evidence for partial resetting, but the cause is more commonly due to differences in annealing properties, as caused by variations in composition for apatite or variations in radiation damage for zircon (Bernet and Garver 2005; Garver et al 2005). Heterogeneous annealing is expected for reset sandstones given that the dated apatites and zircons are derived from a variety of sources (Brandon and Vance 1992). The central age is clearly not appropriate for mixed distributions, in that it provides only an average for all grains. A better approach is to decompose the FTGA distribution into a set of component distributions, and to interpret the FT results using the average ages for those components. In this paper, the binomial 'peak-fitting' method of Galbraith and Green (1990), and Galbraith and Laslett (1993) is used to decompose the FTGA distribution into a set of component distributions. All the samples are composed of several age groups and the young age peaks range between 10-30 Ma 


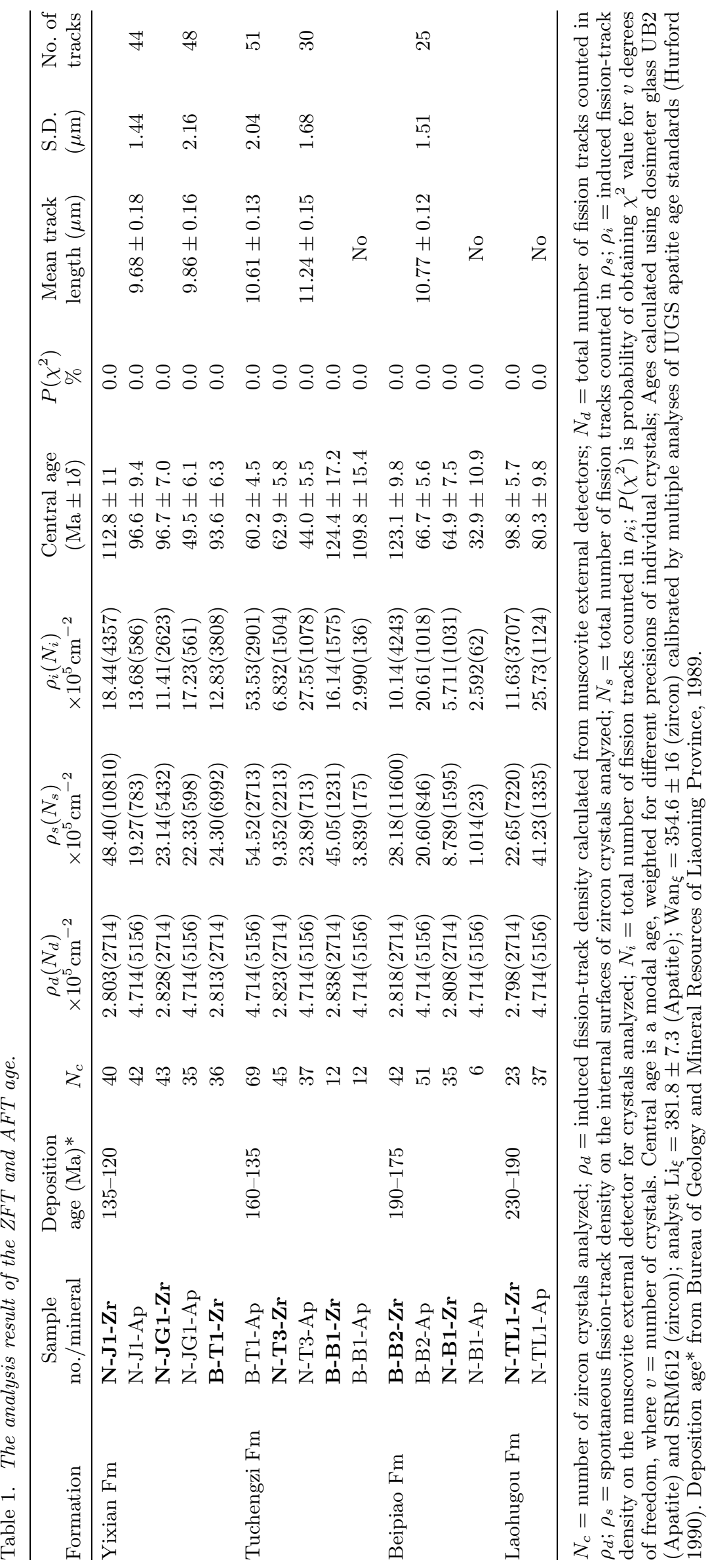




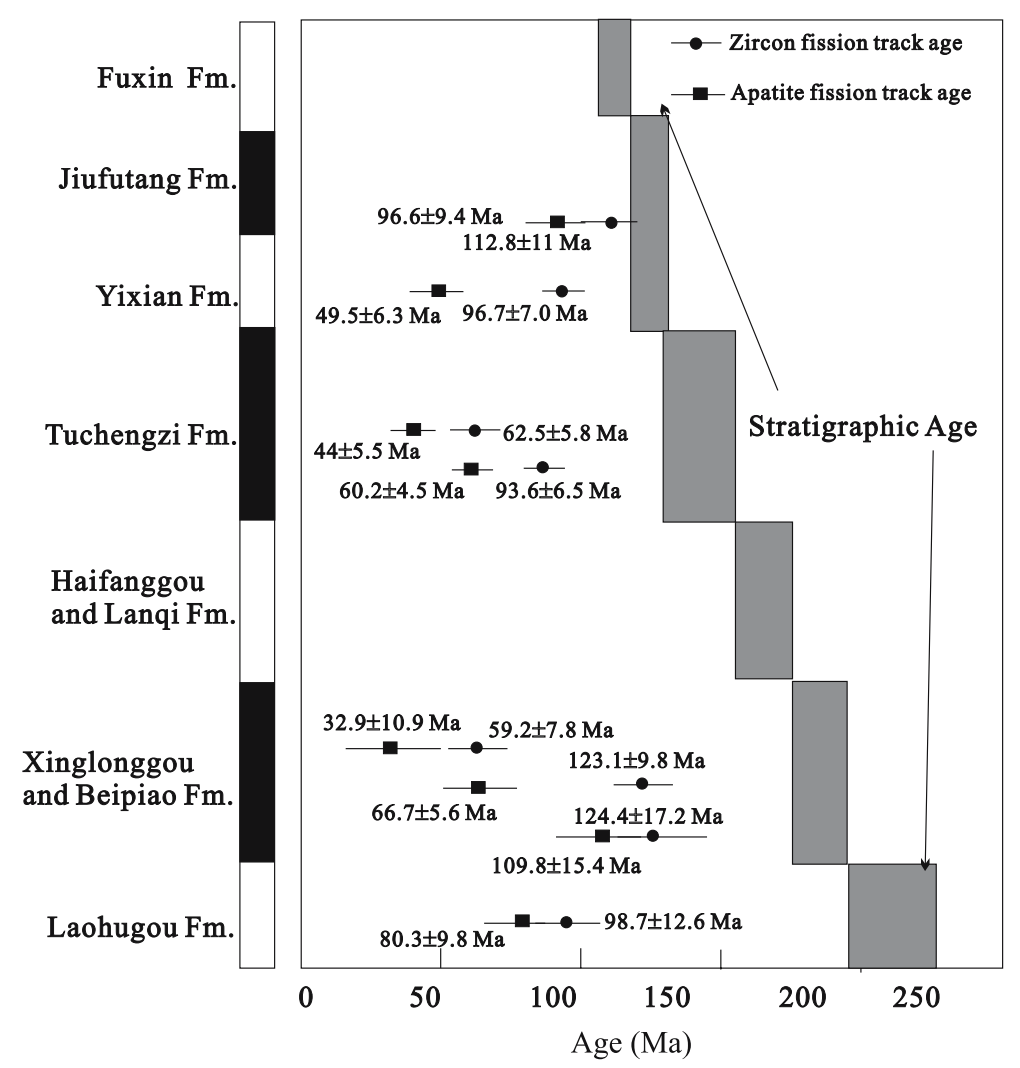

Figure 3. Central fission track ages (from table 1) compared with depositional ages for individual samples from this study.

(AFTA) and 20-50 Ma (ZFTA) except B-B1 with young peak age of $79 \mathrm{Ma}$ (figure 4).

\section{Discussion}

\subsection{Signature of lithosphere thinning in basins}

Detrital ZFT analysis has been used relatively little in post-depositional thermal history analysis due to its high-temperature stability (Garver et al 2005). Recent advancement in the study of ZFT analysis suggests that it is useful to date low-temperature depositional thermal event and exhumation of the strata (Garver et al 2005). In some cases samples may come from deeply buried and heated sequences that possibly be partially or fully reset. Partial resetting of mixed suits of zircon is most conspicuous when sedimentary zircons with a wide range of radiation damage are brought to elevated temperatures $\left(\mathrm{ca} .200^{\circ} \mathrm{C}\right)$, and then allowed to cool. Generally, low-retentive zircons (LRZ) are partially or fully annealed while high-retentive zircons (HRZ) are not annealed after deposition (Garver et al 2005). Full annealing of both LRZ and $\mathrm{HRZ}$ at relatively high temperatures $\left(>300^{\circ} \mathrm{C}\right.$ and above) results young but concordant cooling ages.
As mentioned above, most of the zircon fission track ages are younger than depositional ages and fall in the partial and fully reset zone suggest a widespread reset after deposition (figure 5). Due to zircon fission tracks have an effective annealing temperature of $240^{\circ} \mathrm{C} \pm 30^{\circ} \mathrm{C}$ in natural systems (Hurford and Green 1983; Green et al 1989), zircon can be reset only if it is deeply buried or in a hot geothermal status. The Meso-Cenozoic volcano-sedimentary sequence in the Liaoxi basins is about $4-5 \mathrm{~km}$ thick (Bureau of Geology and Mineral Resources of Liaoning Province 1989; Yan et al 2002; Zhang et al 2005). Early Cretaceous formations mainly developed in the Yixian Basin with limited deposition in the southern Jinyang Basin (Bureau of Geology and Mineral Resources of Liaoning Province 1989; Ma 2001; Zhang et al 2005). Given a normal paleo-geothermal gradient as $30^{\circ} \mathrm{C} / \mathrm{km}$ and average surface temperature as $\sim 20^{\circ} \mathrm{C}$, the highest temperature that the Mesozoic sedimentary rocks experienced in the Liaoxi basins is then determined in a range of around $140-170^{\circ} \mathrm{C}$. At $140-170^{\circ} \mathrm{C}$ temperature range, most of the ZFT of the Jurassic-Cretaceous sedimentary rocks were fairly resistant to thermal annealing and most of ZFT ages were older than their stratigraphic age. It is inconsistent with the above-mentioned results that most of the tracks were reset after deposition. This inconsistency reveals that the sedimentary 

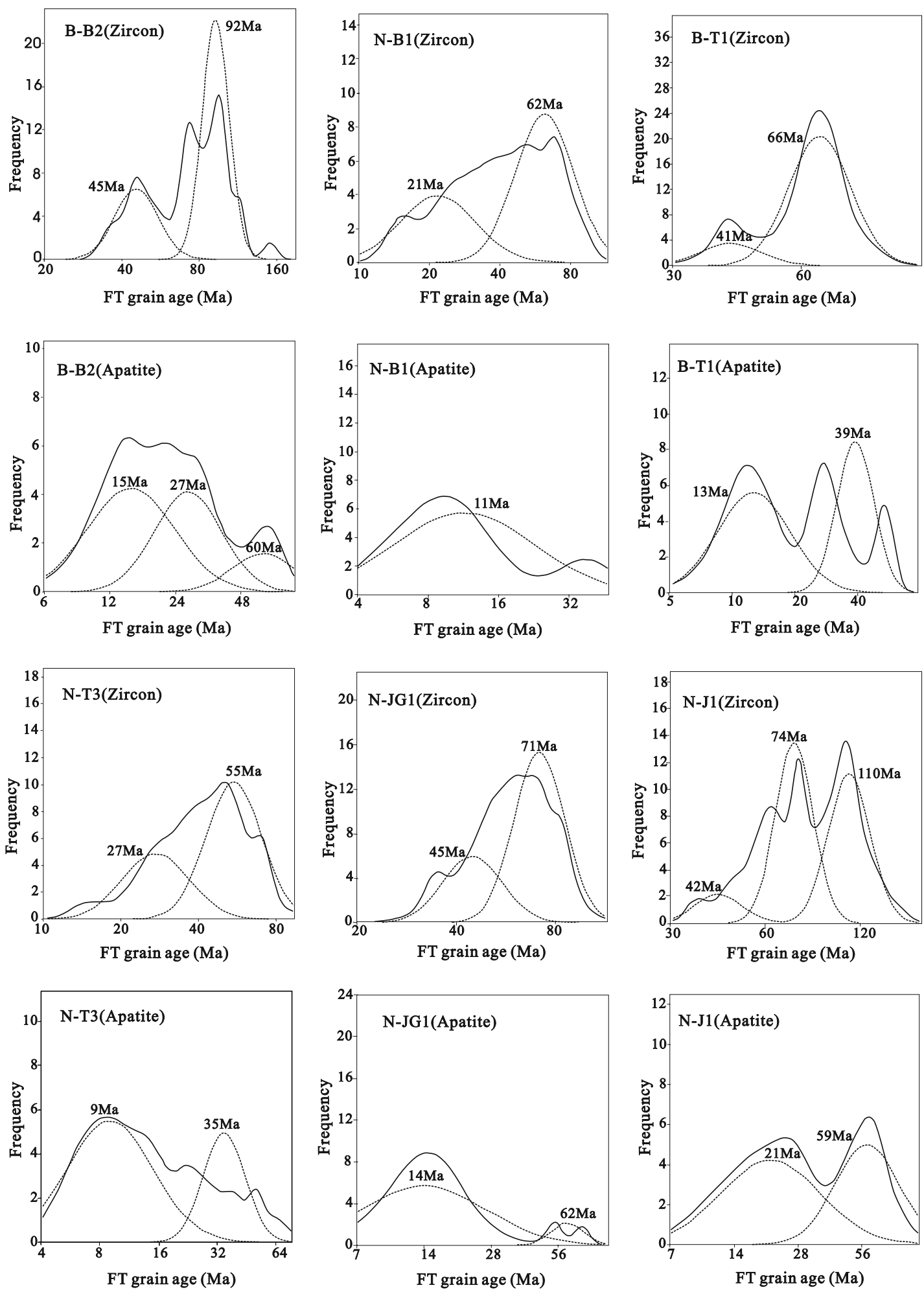

Figure 4. Fission track age decomposition result. Probability density plot (solid line) with best-fit peaks plotted using dashed lines.

rocks in the Liaoxi basins possibly experienced a hot geothermal status after deposition and reset widespread. The discussion is open for the hot geothermal status because zircon fission track reset in the Liaoxi area is affected by the thermal structure of the crust and normal buried. Furthermore, due to widespread volcanism in the Liaoxi area, some of those sediments have been covered by lava flows (such as the Middle Jurassic Lanqi formation and Lower Cretaceous Yixian formation). This can also add some heat to the system, not only because of the flows but also because the magma needs to 

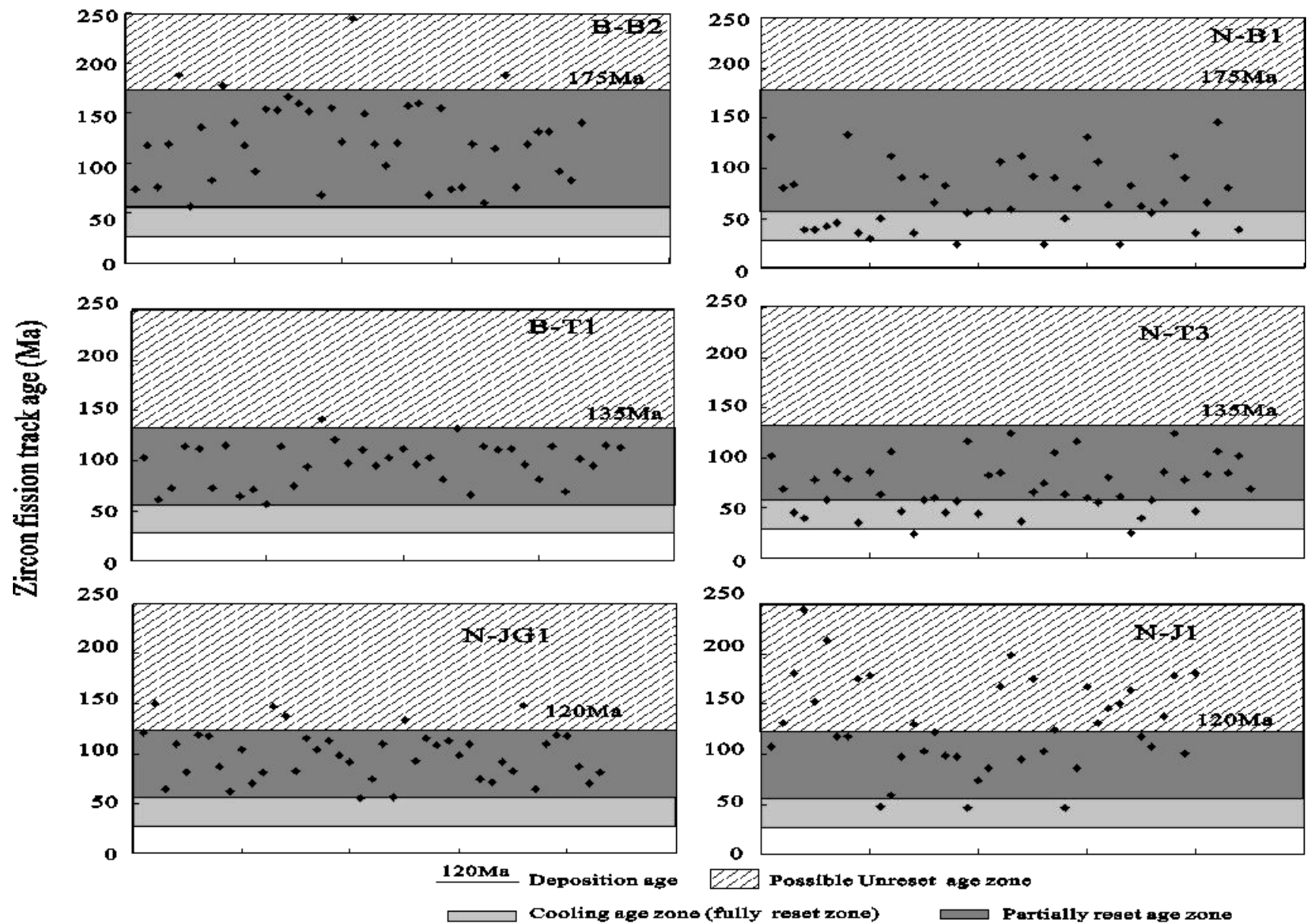

Figure 5. Distribution of ZFT ages from different units in the Liaoxi basins. These Mesozoic sandstones are inferred to have been heated to temperatures in a range of $180-200^{\circ} \mathrm{C}$, which is associated with the lithosphere thinning of the northern margin of the North China Craton (NCC). Depositional ages of these units are Jurassic and Early Cretaceous, so any grains with a possible provenance age (and possible unreset) fall in the deeper gray shaded zone. Subsequent heating (shallow gray shaded zone) apparently fully reset a number of grains that collectively define cooling at ca. 50-20 Ma.

cross the sediment section before being erupted to the surface.

The hot geothermal status in the Liaoxi basins and widespread volcanism in the Liaoxi area is temporal consistent with the lithospheric evolution of the North China Craton. Archaean-Proterozoic crust, atop a thick $(180 \mathrm{~km})$, cold $\left(40 \mathrm{~mW} / \mathrm{m}^{2}\right)$, melt-depleted mantle keel, characterized the North China Craton at the end of the Precambrian. The most recent thermo-tectonic episode in the MesoCenozoic virtually replaced/transformed all of the Precambrian lithosphere. In the Meso-Cenozoic, the eastern craton was the site of major mafic igneous activity (Chen et al 1997; Menzies et al 2007; Zhang et al 2007). By the end of the Cenozoic the eastern part of the craton was characterized by thermal highs $\left(>64 \mathrm{~mW} / \mathrm{m}^{2}\right)$, thin continental lithosphere $(<50 \mathrm{~km})$ and thin crust $(<32 \mathrm{~km})$ adjacent to the intracratonic Bohai Sea (Chen et al 1991; Hu et al 2000a, 2000b). The lithospheric destruction is believed to start since Jurassic time, and the lithosphere was significantly thinned $(<60 \mathrm{~km})$ during $\sim 60 \mathrm{Ma}$ to $40 \mathrm{Ma}$ (Xu 2001). The lithosphere thinning status is also supported by other studies (Xu et al 1995; Shi et al 2000). Thermo-tectonic evolution study based on the geothermo-barometry of garnet-bearing peridotites and pyroxenites brought by alkali basalts to the surface and vitrinite reflectance data shows high heat flow, i.e., $80-100 \mathrm{~mW} / \mathrm{m}^{2}$ during $130-110 \mathrm{Ma}$ (Xu et al 1995; Menzies and Xu 1998; Shi et al 2000). Emplacement of voluminous Late Mesozoic granites and extensive Tertiary volcanism of alkaline basalt that carrying abundant mantle xenoliths indicates that the North China Craton experienced widespread thermo-tectonic reactivation during Late Mesozoic and Cenozoic time. On the basis of numeric models calibrated with VR trends, the palaeo-geothermal gradient of the North China Craton was about $52.5^{\circ} \mathrm{C} / \mathrm{km}$ in Late Mesozoic (Ren 1999). The hot geothermal status in the Liaoxi basins show a similar signature as 
the intracratonic Bohai Sea, which implies that the lithosphere under the northern margin of the North China Craton underwent an analogical thermotectonic destruction process.

\subsection{Uplift of the eastern Yan-Liao Orogenic Belt}

A sedimentary rock that contains both types of zircon derived from different sources generally does not show concordant cooling ages. Galbraith and Laslett (1993) introduced the term 'minimum age', which can be loosely viewed as the pooled age of the largest concordant fraction of young grain ages in an FTGA distribution. For reset rocks, the minimum age represents the time of closure for that fraction of grains with the lowest retention for fission tracks, such as fluorapatites in apatite FT dating (Brandon et al 1998) and radiationdamaged zircons in zircon FT dating (Brandon and Vance 1992). This age pattern represents cooling history of the basin following a high temperature thermal event and can be used to understand lowtemperature thermal event $\left(<300^{\circ} \mathrm{C}\right)$ and exhumation of the strata (Bernet and Garver 2005; Garver et al 2005). Young ZFT age peak of the samples from the Liaoxi basins varies from $\sim 20 \mathrm{Ma}$ to $50 \mathrm{Ma}$ (figure 4), which attributes to cooling following a hot geothermal status during which peak resetting of ZFT took place. The young age, to some extent provides the temporal constraints on the hot geothermal status in the Liaoxi area, which following lithosphere significantly thinned. This time also implies ultimate reverse of the Liaoxi basins and uplift of the eastern part of the Yan-Liao Belt (Davis et al 2001; Meng 2003).

It is important to note that young apatite fission track ages are about $\sim 10 \mathrm{Ma}$ to $30 \mathrm{Ma}$, which more likely reflect further inverse event and uplift of the Liaoxi area. Previous studies revealed that the Circum-Bohai basins subsided quickly at about 30-40 Ma and deposited km-thick clastic sediments (Wang et al 1999), while the Yan-Liao belt experienced inhomogeneous uplift in the Cenozoic $(\mathrm{Wu}$ et al 2000). Furthermore, the palaeo-geothermal gradient in the Liaoxi area was about $30^{\circ} \mathrm{C} / \mathrm{km}$ in the Cenozoic time (Ren 1999) and recent heat flow $64 \mathrm{~mW} / \mathrm{m}^{2}$ (Menzies and Xu 1998). If the FT peak age of $\sim 10$ to $30 \mathrm{Ma}$ did reflect a recent reversing and uplifting event, then it is reasonable to conclude that the 1.5-2 km exhumation occurred since $\sim 10$ to $30 \mathrm{Ma}$ in the eastern part of the Yan-Liao Belt.

\section{Conclusion}

Detrital ZFT and AFT analysis presented here allow us to characterize the thermo-tectonic event in the northern margin of the North China Craton. Detrital ZFT and AFT age distribution imply a hot geothermal status during MesoCenozoic in the Liaoxi basins, which caused ZFT to reset widespread. The thermal status deduced from the Liaoxi basins show a similar signature as the intracratonic Bohai Sea, which indicates that the lithosphere under the northern margin of the North China Craton underwent an analogical thermo-tectonic destruction process. Our results, to some extent provide a temporal constraint on the lithosphere significantly thinned and following reverse of the Liaoxi basins and uplift of the eastern part of the Yan-Liao Orogenic Belt. The northern margin of the North China Craton displays a significant thermo-tectonic evolution process during Meso-Cenozoic.

\section{Acknowledgements}

We express our thanks to Dr Carter from London Thermochronometry Research Group in the University and Birkbeck College for helpful comments. This work was financially co-supported by the Chinese Academy of Sciences (No. KZCX1YW-15-1) and the National Natural Science Foundation of China (Nos. 40776024 and 40972130).

\section{References}

Bernet M and Garter J I 2005 Fission-track analysis of Detrital Zircon; Review in Mineralogy and Geochemistry 58 205-238.

Brandon M T, Roden-Tice M K and Garver J I 1998 Late Cenozoic exhumation of the Cascadia accretionary wedge in the Olympic Mountains, northwest Washington State; GSA Bull. 110 985-1009.

Brandon M T and Vance J A 1992 Tectonic evolution of the Cenozoic Olympic subduction complex, Washington State, as deduced from fission track ages for detrital zircons; Am. J. Sci. 292 565-636.

Bureau of Geology and Mineral Resources of Liaoning Province 1989 Regional Geology of Liaoning Province. Geological Publishing House, Beijing, 150-180 pp (in Chinese with English abstract).

Chen A 1998 Geometric and kinematic evolution of basement-cored structures: Intraplate orogenesis within the Yanshan orogen, northern China; Tectonophys. 292 $17-42$.

Chen L 2010 Concordant structural variations from the surface to the base of the upper mantle in the North China Craton and its tectonic implications; Lithos doi:10.1016/j.lithos.2009.12.007 (in press).

Chen G Y, Song Z H, An C Q, Cheng L H, Zhuang Z, $\mathrm{Fu} \mathrm{Z} \mathrm{W,} \mathrm{Lu} \mathrm{Z} \mathrm{L} \mathrm{and} \mathrm{Hu} \mathrm{J} \mathrm{F} 1991$ Three dimensional crust and upper mantle structure of the North China region; Acta Geophys. Sinica 34 172-181 (in Chinese).

Chen Y X, Chen W J, Zhou X H, Li Z J, Liang H D, Li Q, Xu K, Fan Q C, Zhang G H, Wang F, Wang Y, Zhou S Q, Chen S H, Hu B and Wang Q J 1997 Liaoxi and Adjacent Mesozoic Volcanics-Chronology, Geochemistry and 
Tectonic Settings; The Seismological Press, Beijing, 25pp (in Chinese).

Chen L, Wang T, Zhao L and Zheng T 2008 Distinct lateral variation of lithospheric thickness in the Northeastern North China Craton; Earth Planet. Sci. Lett. 267 $56-68$

Chen L, Cheng C and Wei Z 2009 Seismic evidence for significant lateral variations in lithospheric thickness beneath the central and western North China Craton; Earth Planet. Sci. Lett. 286 171-183.

Davis G A, Wang C, Zheng Y D and Zhang C H 1990 The enigmatic Yanshan fold-and-thrust belt of northern China: New views on its interplate contractional styles; Geology 26 43-46.

Davis G A, Zheng Y D, Wang C, Darby B J and Zhang C H 1998 Mesozoic tectonic evolution of the Yanshan fold and thrust belt, with emphasis on Heibei and Liaoning provinces, northern China; Geol. Soc. Am. Bull. 194 171-197.

Davis G, Zheng Y D, Wang C, Darby B J, Zhang C H and Gehrels G 2001 Mesozoic tectonic evolution of the Yangshan fold and thrust belt, with emphasis on Hebei and Liaoning provinces, northern China; In: Paleozoic and Mesozoic Tectonic Evolution of Central Asia: From Continental Assembly to Intracontinental Deformation (eds) Hendrix H S and Davis G A, Geol. Soc. Am. Memoir 194 171-197. Boulder, Colorado.

Fan W M, Zhang H F, Baker J, Jarvis K E, Mason P R D and Menzies M A 2000 On and off the North China Craton: Where is the Archaean keel?; J. Petrol. 41 933-950.

Galbraith R F and Green P F 1990 Estimating the component ages in a finite mixture; Nuclear Tracks and Radiation Measurements 17 197-206.

Galbraith R F and Laslett G M 1993 Statistical models for mixed fission track ages; Nuclear Tracks and Radiation Measurements 21 459-470.

Gao S, Rudnick R L, Carlson R W, McDonough W F and Liu Y 2002 Re-Os evidence for replacement of ancient mantle lithosphere beneath the North China Craton; Earth Planet. Sci. Lett. 198 307-322.

Gao S, Rudnick R L and Yuan H L 2004 Recycling lower continental crust in the North China Craton; Nature 432 892-897.

Garver J I, Reiners P R, Walker L J, Ramage J R and Perry S E 2005 Implications for timing of Andean uplift based on thermal resetting of radiation-damaged zircon in the Cordillera Huayhuash, northern Perú; J. Geol. 113 117-138.

Green P F, Duddy I R and Laslett G M 1989 Thermal annealing of fission tracks in apatite quantitative modelling techniques and extension to geological timescale; Chem. Geol. 79 155-182.

Griffin W L, Zhang A D, O'Reilly S Y and Ryan C G 1998 Phanerozoic evolution of the lithosphere beneath the Sino-Korean Craton; In: Mantle Dynamics and Plate Interactions in East Asia (eds) Flower M F J, Chung S L, Lo C H and Lee T Y; American Geophysical Union, Geodynamics Series 27 107-126.

Hou G T, Wang Y X and Hari K R 2010 The Late Triassic and Late Jurassic stress fields and tectonic transmission of North China craton; J. Geodyn. doi:10.1016/j.jog.2009.11.007 (in press).

Hu S B, Zhang R Y, Luo Y H and Cai D S 2000a Thermal history of the Bohai Basin and its potential for petroleum; Mar. Petrol. Geol. 5 10-20.

Hu S B, He L and Wang J 2000b Heat flow in the continental area of China: A new data set; Earth Planet. Sci. Lett. 179 407-419.
Hurford A J 1990 Standardization of fission track dating calibration: Recommendation by the Fission Track Working Group of the IUGS Subcommission on Geochronology; Chem. Geol. (Isotopic Geoscience Section) 80 171-178.

Hurford A J and Green P F 1983 The zeta age calibration of fission-track dating; Chem. Geol. (Isotope Geoscience Section) 1 285-317.

Li S G, Xiao Y L, Liou D L, Chen Y Z, Ge N J, Zhang Z Q, Sun S S, Cong B L, Zhang R Y, Hart S R and Wang S S 1993 Collision of the North China and Yangtze Blocks and formation of coesite-bearing eclogites - Timing and processes; Chem. Geol. 109 89-111.

Liu D Y, Nutman A P, Compston W, Wu J S and Shen Q H 1992 Remnants of $3800 \mathrm{Ma}$ crust in the Chinese part of the Sino-Korean craton; Geology 20 339-342.

Ma Y S 2001 The evolution of Mesozoic-Cenozoic basinmountain structure in the east Yanshan area and Xialiaohe Basin; J. Geomechanics 7(1) 79-90 (in Chinese with English abstract).

Meng Q R 2003 What drove late Mesozoic extension of the northern China-Mongolia tract?; Tectonophys. 369 $155-174$.

Meng Q R and Zhang G W 2000 Geologic framework and tectonic evolution of the qinling orogen, central China; Tectonophys. 323 183-196.

Menzies M A, Xu Y G, Zhang H F and Fan W M 2007 Integration of geology, geophysics and geochemistry: A key to understanding the North China Craton; Lithos 96 1-21.

Menzies M A and Xu Y G 1998 Geodynamics of the North China Craton; In: Mantle Dynamics and Plate Interactions in East Asia (eds) Flower M F J, Chung S L, Lo C H and Lee T Y; American Geophysical Union, Geodynamics Series $\mathbf{2 7}$ 155-165.

Ren J Y, Tamaki K, Li S T and Zhang J X 2002 Late Mesozoic and Cenozoic rifting and its dynamics setting in eastern China and adjacent areas; Tectonophys. 344 $175-205$.

Ren Z L 1999 Study on the thermo-tectonic evolution of basin in north of China; Petroleum Industry Press, Beijing, 59-97 pp (in Chinese).

Santosh M 2010 Assembling North China Craton within the Columbia supercontinent: The role of double-sided subduction; Precamb. Res. 178 149-167, doi:10.1016/j.precamres.2010.02.003.

Santosh M, Zhao D and Kusky T 2010 Mantle dynamics of the Paleoproterozoic North China Craton: A perspective based on seismic tomography; J. Geodyn. 49 39-53.

Shi L B, Lin C Y, Chen X D and Han X L 2000 A xenolithderived geotherm for the lower crust and upper mantle beneath Hannuoba area, Hebei province, China and its geologic implications; Seismol. Geol. 22 37-46 (in Chinese with English abstract).

Tian Y, Zhao D, Sun R and Teng J 2009 Seismic imaging of the crust and upper mantle beneath the North China Craton; Physics of the Earth and Planetary Interiors 172 169-182.

Trap P, Faure M, Lin W, Monie P, Meffre S and Melleton J 2009 The Zanhuang Massif, the second and eastern suture zone of the Paleoproterozoic Trans-North China Orogen; Precamb. Res. 172 80-98.

Wang T H, Wang X S and Han Y C 1999 The Tectonic Evolution and Oil Accumulation in North China Craton; Petroleum Industry Press, Beijing, 118-135 pp (in Chinese).

Wu Z H, Cui S Q and Wu G G 2000 Thermochronological analysis on the uplift process of the Yanshan Mountains; Geol. Rev. 46(1) 49-57 (in Chinese with English abstract). 
Wu F Y, Walker R J, Ren X W, Sun D Y and Zhou X H 2003 Osmium isotopic constraints on the age of lithospheric mantle beneath northeastern China; Chem. Geol. 196 107-129.

Wu G Y, Liang X and Chen H J 2007 An approach to the Tancheng-Lujiang fault zone: Its creation, evolution and character; Chinese J. Geol. 42(1) 160-175.

Xiao W J, Windley B F, Hao J and Zhai M G 2003 Accretion leading to collision and the Permian Solonker suture, Inner Mongolia, China: Termination of the central Asian orogenic belt; Tectonics 22(6) 2-20.

Xiao W J, Windley B F, Han C M, Yuan C, Sun M, Li J L and Sun S 2009 End Permian to mid-Triassic termination of the southern Central Asian Orogenic Belt; Int. J. Earth Sci. 98 1189-1217.

Xiao W J, Huang B C, Han C M, Sun S and Li J L 2010 A review of the western part of the Altaids: A key to understanding the architecture of accretionary orogens; Gondwana Res., doi:10.1016/j.gr.2010.01.007 (in press).

Xu Y G 2001 Thermo-tectonic destruction of the Archaean lithospheric keel beneath the Sino-Korean Craton in China: Evidence, timing and mechanism; Physics and Chemistry of the Earth (A) 26 747-757.

$\mathrm{Xu} \mathrm{P}$ and Zhao D 2009 Upper mantle velocity structure beneath the North China Craton: Implications for lithospheric thinning; Geophys. J. Int. 177 1279-1283.

Xu Y G, Lin C Y, Shi L B, Mercier J C C and Ross J V 1995 Upper mantle geotherm for eastern China and its geological implications; Science in China (Series B) $\mathbf{3 8}$ 1482-1492.

Yan Y, Lin G and Li Z A 2002 Characteristic of Jurassic filling sequence and the indication to the tectonic evolution of Beipiao basin in western Liaoning province; J. Stratigraphy 26(2) 10-14 (in Chinese with English abstract).

Zhang Y S 1998 Three-dimensional upper mantle structure beneath East Asia and its tectonic implications. In: Mantle Dynamics and Plate Interactions in East Asia (eds) Flower M F J, Chung S L, Lo C H and Lee T Y; American Geophysical Union, Geodynamics Series $\mathbf{2 7}$ $11-23$.
Zhang H F, Sun M, Zhou M F, Fan W M and Zheng J P 2003 Secular evolution of the lithosphere beneath the eastern North China Craton: Evidence from Mesozoic basalts and high-Mg andesites; Geochim. Cosmochim. Acta 67 43734387.

Zhang H, Liu X M, Li Z T, Yang F L and Wang X R 2005 Early Cretaceous large-scale crustal thinning in the Fuxin-Yixian Basin and adjacent area in Western Liaoning; Geol. Rev. 51(4) 360-369 (in Chinese with English abstract).

Zhang H F, Ying J F, Shimoda G, Kita N T, Morishita Y, Shao J A and Tang Y J 2007 Importance of melt circulation and crust-mantle interaction in the lithospheric evolution beneath the North China Craton: Evidence from Mesozoic basalt-borne clinopyroxene xenocrysts and pyroxenite xenoliths; Lithos 96 67-89.

Zhao G C, Cawood P A, Wilde S A and Sun M 2002 Review of global 2.1-1.8 Ga collisional orogens and accreted cratons: A pre-Rodinia supercontinent?; Earth Sci. Rev. 59 125-162.

Zhao G C, Sun M, Wilde S A and Li S Z 2005 Late Archean to Paleoproterozoic evolution of the North China Craton: Key issues revisited; Precamb. Res. 136 177-202.

Zhao G C, Wilde S A, Sun M, Li S Z, Li X P and Zhang J 2008 SHRIMP U-Pb zircon ages of granitoid rocks in the Lüliang Complex: Implications for the accretion and evolution of the Trans-North China Orogen; Precamb. Res. $160213-226$

Zhao G C, He Y and Sun M 2009 The Xiong'er volcanic belt at the southern margin of the North China Craton: Petrographic and geochemical evidence for its outboard position in the Paleo-Mesoproterozoic Columbia Supercontinent; Gondwana Res. 16 170-181.

Zhao G C, Wilde S A, Guo J H, Cawood P A, Sun M and Li X P 2010 Single zircon grains record two Paleoproterozoic collisional events in North China Craton; Precamb. Res. 177 266-276.

Zheng J P, O'Reilly S Y, Griffin W L, Lu F X, Zhang M and Pearson N J 2001 Relict refractory mantle beneath the eastern North China block: Significance for lithosphere evolution; Lithos $\mathbf{5 7}$ 43-66. 